\title{
ANALISA POTENSI GENANGAN BERDASARKAN DATA CURAH HUJAN GLOBAL TRMM (TROPICAL RAINFALL MEASURING MISSION) (Studi Kasus : Kabupaten Sampang)
}

\author{
Filsa Bioresita, Muhammad Taufik \\ Program Studi Teknik Geomatika FTSP-ITS, Kampus ITS Sukolilo, Surabaya, 60111 \\ Email : bioresita09@mhs.geodesy.its.ac.id, taufik_srmd@yahoo.com
}

\begin{abstract}
Abstrak
Indonesia memiliki suatu problematika yang terjadi tiap tahun yaitu bencana banjir. Salah satu penyebab terjadinya banjir adalah adanya genangan air yang terjadi pada suatu tempat dalam kurun waktu tertentu. Salah satu cara untuk dapat mengelola resiko terjadinya genangan adalah dengan memperkirakan kapan suatu daerah akan berpotensi terkena genangan. Analisa ini dapat dilakukan dengan memperkirakan potensi terjadinya hujan lebat (curah hujan tinggi) yang diturunkan dari data curah hujan global yaitu data TRMM (Tropical Rainfall Measuring Mission) dan diintegrasikan dengan peta penggunaan lahan, peta jenis tanah, serta Digital Elevation Model (DEM).

Wilayah yang dikaji pada penelitian adalah Kabupaten Sampang yang terletak di $113^{\circ} 08^{\prime}-113^{\circ} 39^{\prime}$ Bujur Timur dan $6^{\circ}$ $05^{\prime}-7^{\circ} 13^{\prime}$ Lintang Selatan. Pengolahan data dimulai dengan ekstraksi data TRMM menjadi data curah hujan dan koordinat pengukuran hujan. Data curah hujan hasil ekstraksi dari citra TRMM divalidasi dengan data curah hujan di lapangan kemudian digunakan untuk pembuatan peta curah hujan. Peta curah hujan tersebut ditampalkan dengan peta ketinggian wilayah dan peta kelerengan hasil dari pengolahan Digital Elevation Model, serta peta jenis tanah dan peta penggunaan lahan. Menggunakan metode skoring, hasil pertampalan menghasilkan data spasial baru berupa daerah potensi genangan.

Dari hasil analisa didapat nilai korelasi yang tinggi antara data curah hujan TRMM dengan data curah hujan di lapangan. Daerah potensi genangan tinggi hasil analisa memiliki kecocokan dengan data kejadian banjir. Namun terdapat daerah potensi genangan tingkat tinggi yang berada di sebelah utara Kabupaten Sampang yang belum terbukti kebenaranya. Oleh karena itu perlu adanya penelitian tentang daerah potensi genangan di utara Kabupaten Sampang. Analisa hubungan antara data curah hujan TRMM dengan potensi genangan menunjukkan bahwa terdapat hubungan antara intensitas curah hujan dengan tingkat potensi genangan.
\end{abstract}

Kata Kunci: Potensi Genangan, TRMM, DEM, Metode Skoring, dan Kabupaten Sampang

\section{PENDAHULUAN}

\section{Latar Belakang}

Indonesia merupakan negara yang memiliki dua musim yaitu musim kemarau dan musim penghujan. Saat musim penghujan tiba, Indonesia memiliki suatu problematika yang terjadi tiap tahun yaitu bencana banjir. Bencana banjir mengakibatkan banyak kerugian baik korban jiwa maupun material. Salah satu penyebab terjadinya banjir adalah adanya genangan air yang terjadi pada suatu tempat dalam kurun waktu tertentu. Salah satu cara untuk dapat mengelola resiko terjadinya genangan adalah dengan memperkirakan kapan suatu daerah akan berpotensi terkena genangan. Analisa ini dapat dilakukan dengan memperkirakan potensi terjadinya hujan lebat (curah hujan tinggi) yang diturunkan dari data curah hujan global yaitu data TRMM (Tropical Rainfall Measuring Mission) dan diintegrasikan dengan peta penggunaan lahan, peta jenis tanah, serta DEM. Hasil dari penggunaan teknik analisis tersebut berupa informasi prakiraan potensi genangan.

Kabupaten Sampang merupakan salah satu daerah yang sering dilanda banjir. Pada tanggal 13 November 2012 terjadi banjir yang menyebabkan kawasan perkotaan di Kabupaten Sampang dikepung banjir (Kompas 2012). Namun banjir yang terjadi secara berkala ini harus dicari solusinya agar tidak menimbulkan kerugian yang semakin meningkat.

Pemanfaatan data curah hujan global TRMM untuk mendukung pembangunan sistem 
peringatan dini bencana banjir diyakini sebagai suatu teknik yang dapat memberi kontribusi sangat banyak. Oleh karena itu, dalam penelitian ini akan dibangun suatu kajian data curah hujan global yaitu data TRMM yang mempunyai resolusi temporal dan cakupan wilayah yang relatif luas, untuk analisa potensi genangan. Kajian tersebut diperlukan sebagai upaya mengelola resiko terjadinya banjir dan kerugian akibat bencana banjir.

\section{Batasan Masalah}

1. Wilayah studi yang digunakan dalam penelitian ini adalah wilayah Kabupaten Sampang.

2. Analisa daerah potensi genangan dilakukan berdasarkan data TRMM, DEM, peta penggunaan lahan, dan peta jenis tanah.

3. Analisa hubungan berdasarkan dua variabel yaitu genangan dan curah hujan.

\section{Tujuan Penelitian}

Tujuan penelitian ini adalah :

1. Mengetahui estimasi curah hujan di Kabupaten Sampang.

2. Pembuatan peta daerah potensi genangan di Kabupaten Sampang.

3. Mengetahui hubungan antara genangan dengan data curah hujan TRMM.

\section{METODOLOGI PENELITIAN}

\section{Lokasi Penelitian}

Lokasi penelitian ini mengambil daerah studi di Kabupaten Sampang yang terletak di $113^{\circ} 08^{\prime}$ $113^{\circ} 39^{\prime}$ Bujur Timur dan $6^{\circ} 05^{\prime}-7^{\circ} 13^{\prime}$ Lintang Selatan.

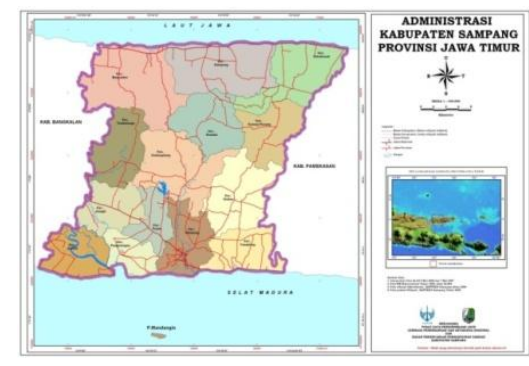

Gambar 1. Lokasi Penelitian (Sumber : BAPPEDA Kabupaten Sampang)

\section{Data Dan Peralatan}

\section{- Data}

Data yang digunakan dalam penelitian ini adalah:

1. Data TRMM 3B43 tahun 2008-2010.

2. Peta RBI Kabupaten Sampang Skala 1:25.000.

3. Peta Penggunaan Lahan Kabupaten Sampang skala 1:50.000.

4. Peta Jenis Tanah Kabupaten Sampang skala 1:50.000.

5. Peta Jaringan Sungai Kabupaten Sampang skala 1:50.000

6. Peta Batas Kecamatan Kabupaten Sampang skala 1:50.000

7. Data curah hujan Kabupaten Sampang dari BMKG tahun 2008-2010.

8. Data kejadian banjir tahun 2010.

\section{- Peralatan}

Peralatan yang digunakan dalam penelitian ini adalah:

1. Perangkat Keras (Hardware)
a. Laptop
b. Printer

2. Perangkat Lunak (Software)
a. Sistem Operasi Windows 7
b. Microsoft Office 2007
c. Orbit Viewer THOR (Tool for High- resolution Observation Review)
d. ArcGIS 9.3
e. AutoCAD LandDesktop 2009
f. SPSS Statistics 17.0 


\section{Diagram Alir Pengolahan Data}

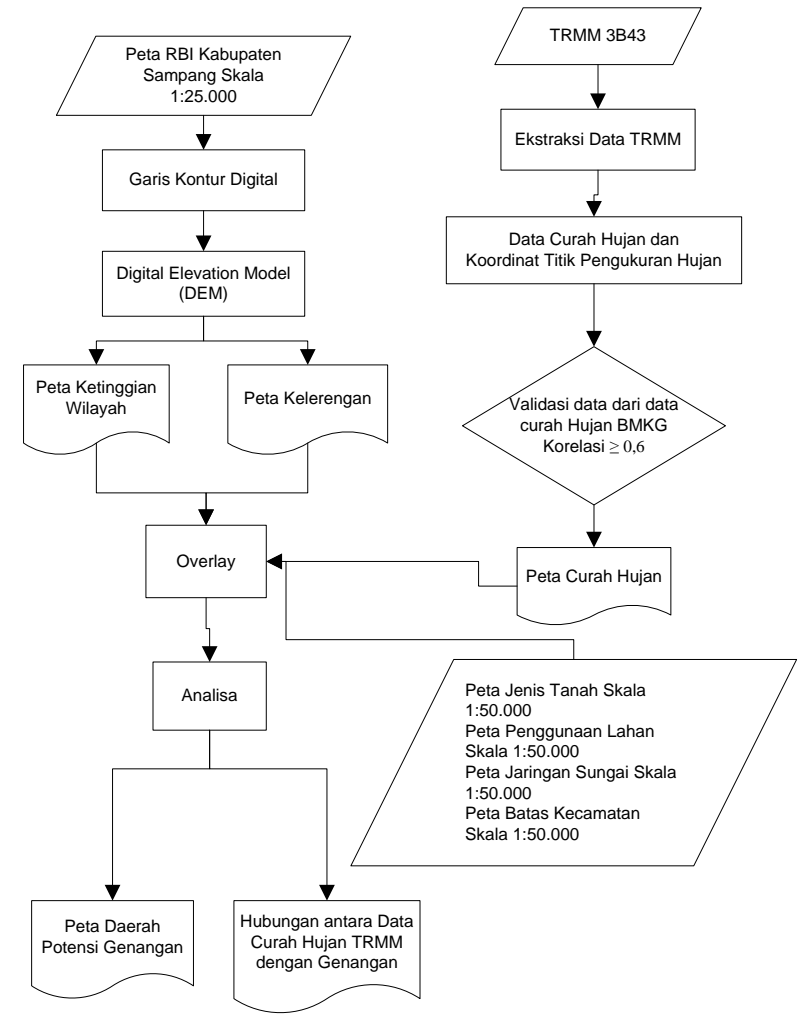

Gambar 2. Diagram Alir Tahap Pengolahan Data

Penjelasan dari diagram alir diatas adalah :

1. DEM

Pada tahap ini dilakukan pembentukan DEM dari garis kontur yang terdapat pada peta RBI hingga menghasilkan suatu peta ketinggian wilayah dan peta kelerengan.

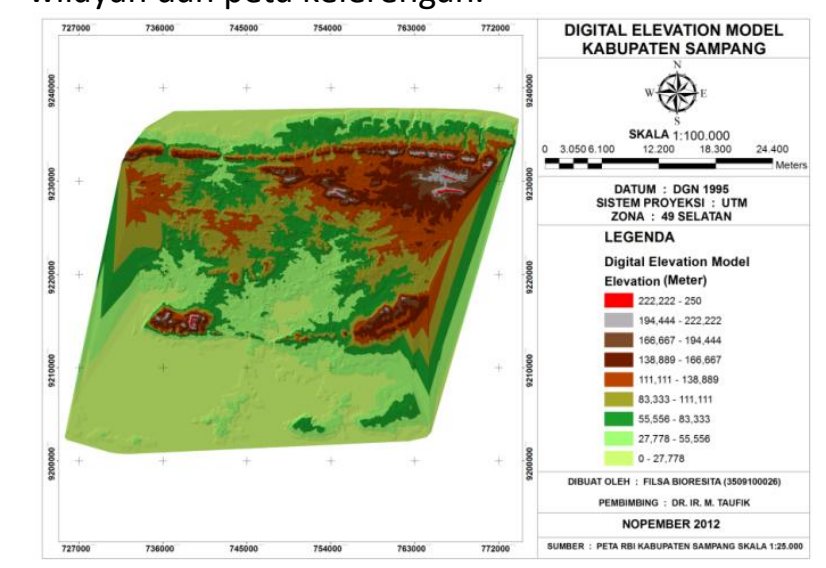

Gambar 3. Digital Elevation Model (DEM) sebagai dasar pembuatan Peta Ketinggian Wilayah dan Peta Kelerengan

\section{Citra TRMM}

Data citra TRMM 3B43 diekstrak menggunakan perangkat lunak software Orbit Viewer THOR
(Tool for High-resolution Observation Review), untuk mendapatkan data curah hujan dan koordinat titik pengukuran hujan. Data hasil ekstraksi tersebut divalidasi dengan data curah hujan dari BMKG. Validasi dilakukan dengan analisa korelasi. Apabila nilai korelasi $\geq 0,6$ maka data dapat digunakan untuk pembuatan peta curah hujan. Acuan nilai korelasi $\geq 0,6$ ini didasarkan pada interpretasi nilai korelasi 0,6 yang berarti korelasi sedang. Selain itu, didasarkan pula pada perhitungan dalam penelitian ini, dimana nilai korelasi $\geq 0,6$ menyatakan ada hubungan signifikan antar variabel dengan tingkat signifikan $5 \%$.

\section{Overlay}

Pada tahap ini dilakukan metode skoring untuk tiap kelas parameter genangan. Melalui metode ini, diberikan bobot dan skor untuk masing-masing kelas parameter genangan. Kemudian, masing-masing parameter tersebut ditampalkan (overlay). Dari tahap ini akan dihasilkan data spasial baru berupa data analisa daerah potensi genangan. Analisa daerah potensi genangan didasarkan pada nilai total skor dari masing-masing area. Area yang memiliki total skor atau nilai paling tinggi merupakan area yang paling berpotensi untuk tergenang.

Dilakukan juga overlay dengan peta jaringan sungai dan peta batas kecamatan untuk mengetahui nantinya daerah potensi genangan berada di kecamatan mana dan dekat dengan sungai apa.

\section{Analisa}

Pada tahap analisa ini, dilakukan validasi peta daerah potensi genangan yang dihasilkan. Validasi dilakukan dengan menghitung tingkat korelasi antara daerah potensi genangan tingkat tinggi pada beberapa daerah dengan data kejadian banjir tahun 2010. Validasi ini dilakukan untuk mengetahui seberapa besar tingkat kepercayaan yang didapatkan dari peta daerah potensi genangan yang dihasilkan.

Kemudian dianalisa hubungan antara data curah hujan TRMM dengan tingkat potensi genangan yang dihasilkan. Analisa dilakukan menggunakan tabel kontingensi atau yang 
sering disebut tabulasi silang (cross tabulation atau cross classification). Dengan tabel kontingensi, dapat ditunjukkan hubungan antara dua variabel yang bersifat kategorik. Ada tidaknya hubungan diketahui melalui uji chi-square dari tabel tersebut.

5. Hasil akhir

Hasil akhir dari penelitian ini adalah Peta daerah potensi genangan di Kabupaten Sampang dan hubungan antara intensitas curah hujan TRMM dengan tingkat potensi genangan.

\section{HASIL DAN PEMBAHASAN}

\section{Ekstraksi Data TRMM}

Dalam penelitian ini, digunakan data curah hujan TRMM 3B43 yang merekam curah hujan rata-rata per jam dalam interval per bulan dengan area cakupan grid $0,25^{\circ} \times 0,25^{\circ}$. Data yang digunakan adalah data dari tahun 2008-2010. Setiap data TRMM 3B43 diolah menggunakan software Orbit Viewer THOR (Tool for High-resolution Observation Review) untuk mendapatkan nilai curah hujan per grid pada area penelitian.

\section{Validasi Data TRMM}

Proses validasi data dilakukan untuk mengetahui kesesuaian antara data TRMM dengan data lapangan (data curah hujan dari BMKG). Validasi dilakukan dengan uji korelasi antara kedua data tersebut menggunakan t-test. Berikut adalah hasil korelasi antara data curah hujan TRMM dengan data curah hujan BMKG per tahun.

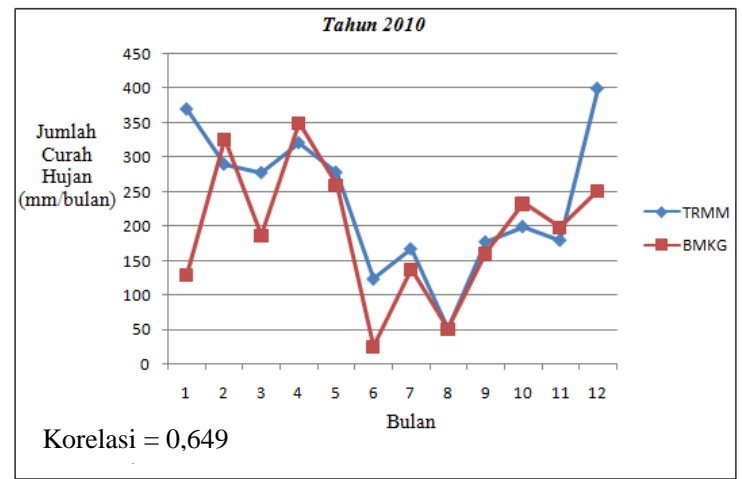

Gambar 4. Korelasi antara Data Curah Hujan TRMM dengan Data Curah Hujan BMKG Tahun 2010

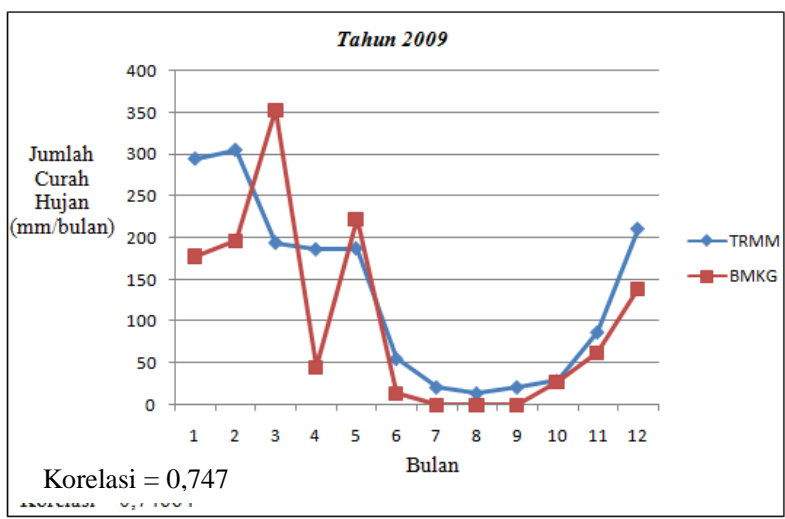

Gambar 5. Korelasi antara Data Curah Hujan TRMM dengan Data Curah Hujan BMKG Tahun 2009

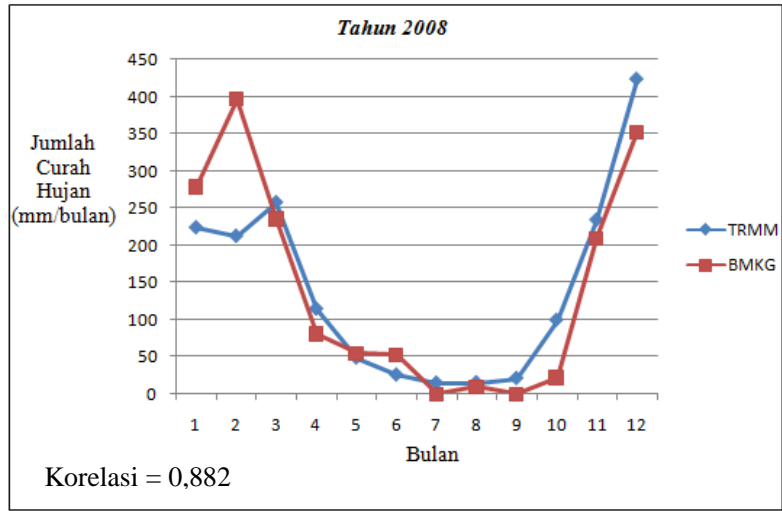

Gambar 6. Korelasi antara Data Curah Hujan TRMM dengan Data Curah Hujan BMKG Tahun 2008

Hasil korelasi antara data TRMM dengan data BMKG, menunjukkan rata-rata korelasi yang baik, yaitu 0,759. Disamping itu, nilai korelasi tiap tahun juga menunjukkan hasil yang cukup baik, yaitu diatas 0,6 . Nilai ketiga korelasi tersebut diuji untuk mendapatkan makna hubungan variabel $X$ terhadap $Y$. Pengujian dilakukan dengan menggunakan Uji-t dengan tingkat signifikan $\alpha=$ $5 \%$. Hasilnya menunjukkan bahwa terdapat hubungan yang signifikan antar curah hujan TRMM dengan curah hujan BMKG.

\section{Curah Hujan}

Berikut ini adalah data curah hujan TRMM dari tahun 2008-2010 yang telah diakumulasi menjadi jumlah curah hujan per tahun. 
Tabel 1. Data Jumlah Curah Hujan Tahun 2008 - 2010

\begin{tabular}{|c|c|c|c|c|}
\hline \multirow{2}{*}{ Grid } & \multirow{2}{*}{$\begin{array}{l}\text { Koordinat } \\
\text { Tengah }\end{array}$} & \multicolumn{3}{|c|}{ Jumlah Curah Hujan (mm/tahun) } \\
\hline & & 2008 & 2009 & 2010 \\
\hline 1 & $\begin{array}{l}6.875^{\circ} \mathrm{LS} \\
113.125^{\circ} \mathrm{BT}\end{array}$ & 1660.965607 & 1524.642077 & 2900.613588 \\
\hline 2 & $\begin{array}{l}6.875^{\circ} \mathrm{LS} \\
113.375^{\circ} \mathrm{BT}\end{array}$ & 1607.740966 & 1505.617913 & 2790.577608 \\
\hline 3 & $\begin{array}{l}7.125^{\circ} \mathrm{LS} \\
113.125^{\circ} \mathrm{BT}\end{array}$ & 1816.814789 & 1765.576349 & 2889.780953 \\
\hline 4 & $\begin{array}{l}7.125^{\circ} \mathrm{LS} \\
113.375^{\circ} \mathrm{BT}\end{array}$ & 1672.58963 & 1620.871104 & 2780.250223 \\
\hline & Rata-rata & 1689.527748 & 1604.176861 & 2840.305593 \\
\hline
\end{tabular}

Dari Tabel 1. dapat dilihat bahwa terjadi perubahan curah hujan dari tahun 2008 hingga tahun 2010. Dari rata-rata curah hujan pada tahun 2008 sebesar 1689,527748 $\mathrm{mm}$ berkurang menjadi 1604,176861 mm pada tahun 2009 dan kemudian naik kembali menjadi $2840,305593 \mathrm{~mm}$ pada tahun 2010. Dapat dilihat bahwa tahun 2010 memiliki rata-rata jumlah curah hujan yang paling tinggi.

Dari ketiga tahun pengolahan data curah hujan, dapat disimpulkan bahwa rata-rata bulan basah adalah antara 4-5 bulan dan rata-rata bulan kering adalah antara 6-7 bulan. Hal tersebut berdasarkan klasifikasi iklim untuk daerah Asia Tenggara oleh LR. Oldeman, 1974 (Benyamin Lakitan, 1991 dalam Lukman 2011).

Berikut ini adalah Peta Curah Hujan Kabupaten Sampang yang didapatkan dari pengolahan data curah hujan TRMM tahun 2010. Peta ini yang nantinya akan digunakan sebagai salah satu variabel penentu daerah potensi genangan.

Dari gambar tersebut dapat diketahui bahwa Kecamatan Banyuates termasuk dalam area dengan intensitas curah hujan tertinggi di Kabupaten Sampang. Namun dikarenakan Kecamatan Banyuates sebagian besar berada di wilayah yang relatif tinggi, maka tidak ada laporan tentang adanya genangan di area tersebut. Laporan area tergenang yang ada adalah di Kecamatan Sampang. Apabila dikaitkan dengan intensitas curah hujan, terdapat pengaruh yang jelas. Seperti tampak pada gambar, Sebagian wilayah Kecamatan Sampang berada pada area yang memiliki intensitas curah hujan tertinggi kedua yaitu $2889,8 \mathrm{~mm} /$ tahun.

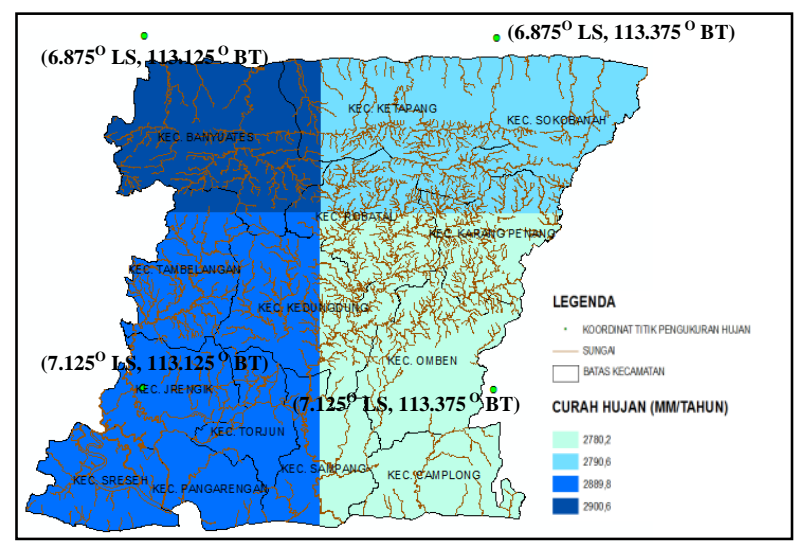

Gambar 7. Peta Curah Hujan Kabupaten Sampang Tahun 2010

\section{Digital Elevation Model (DEM)}

Dalam tahap ini dilakukan proses pembuatan Digital Elevation Model (DEM) dari garis kontur pada Peta RBI Kabupaten Sampang skala 1:25.000. DEM ini berfungsi untuk pembuatan Peta Ketinggian Wilayah dan Peta Kelerengan.

Berikut ini adalah Peta Ketinggian Wilayah hasil dari pengolahan DEM.

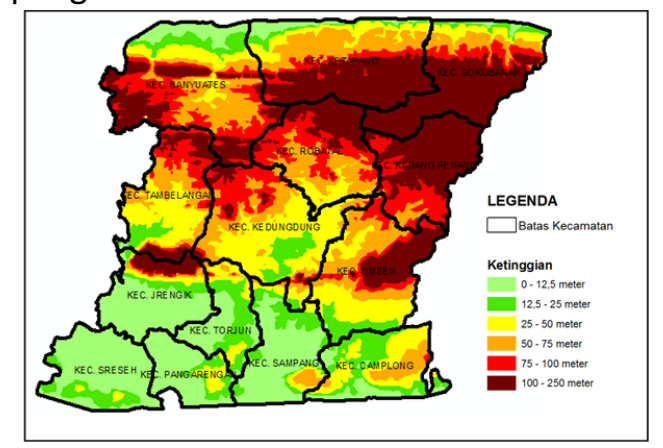

Gambar 8. Peta Ketinggian Wilayah Kabupaten Sampang

Dari Peta Ketinggian Wilayah tersebut dapat diketahui bahwa Kabupaten Sampang memiliki wilayah dataran rendah paling banyak di daerah selatan. Sehingga kemungkinan daerah tergenang pada area tersebut semakin banyak. Area Kecamatan Sampang memiliki wilayah yang relatif rendah. Hal ini yang menyebabkan Kecamatan Sampang memiliki potensi yang besar untuk tergenang. Dibuktikan dengan laporan kejadian banjir yang ada, Kecamatan Sampang merupakan daerah yang sering dilanda banjir. 
Berikut ini adalah Peta Kelerengan Kabupaten Sampang hasil dari pengolahan DEM.

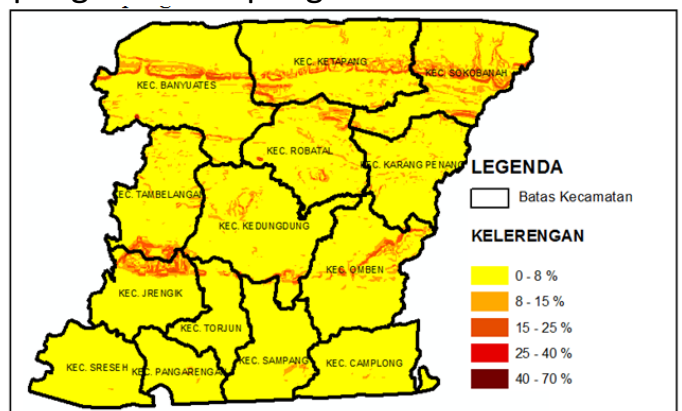

Gambar 9. Peta Kelerengan Kabupaten Sampang

Dari Peta Kelerengan tersebut dapat diketahui bahwa Kabupaten Sampang memiliki wilayah yang relatif datar. Sebagian besar kemiringan lahannya adalah 0-8\%. Hal tersebut menjadikan sebagian besar daerah pada Kabupaten Sampang berpotensi untuk tergenang.

\section{Jenis Tanah Kabupaten Sampang}

Dari Peta Jenis Tanah Kabupaten Sampang Skala 1:50.000 yang bersumber dari BAPPEDA (Badan Perencanaan dan Pembangunan Daerah) Kabupaten Sampang, dibuat suatu peta sebagai berikut.

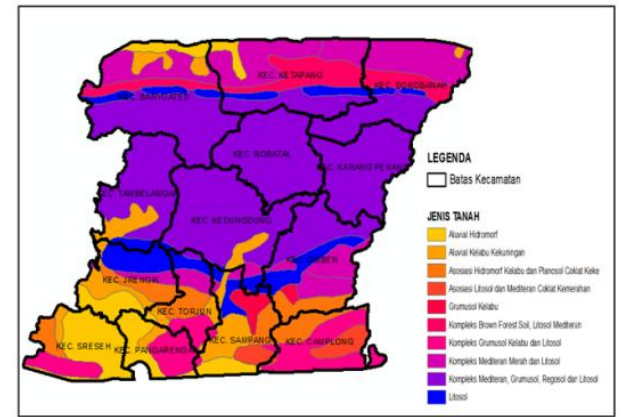

Gambar 10. Peta Jenis Tanah Kabupaten Sampang

Dapat diketahui bahwa jenis tanah di Kabupaten Sampang didominasi oleh Kompleks Mediteran, Grumosol, Regosol, dan Litosol. Serta dapat dilihat pula bahwa area di sebelah selatan Kabupaten Sampang memiliki banyak jenis tanah Alluvial, sehingga memiliki potensi yang besar untuk tergenang.

\section{Penggunaan Lahan Kabupaten Sampang Tahun 2009}

Data penggunaan lahan didapatkan dari Peta Penggunaan Lahan Kabupaten Sampang Tahun 2009 Skala 1:50.000 yang bersumber dari
BAPPEDA Kabupaten Sampang. Berikut ini adalah peta penggunaan lahan tersebut.

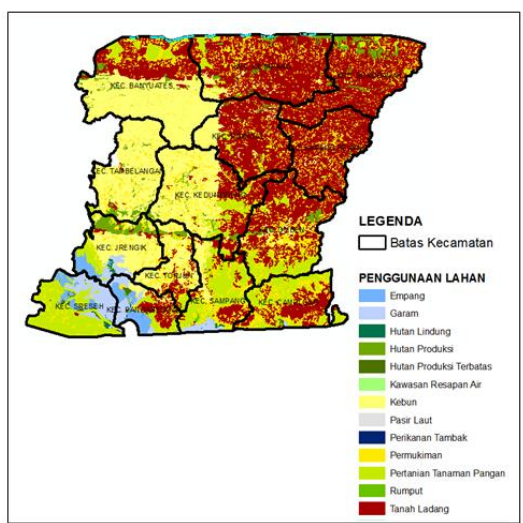
Gambar 11. Peta Penggunaan Lahan Kabupaten
Sampang

Penggunaan lahan terbesar adalah pada tanah ladang dan penggunaan lahan terumbu karang merupakan penggunaan lahan terkecil.

\section{Jaringan Sungai Kabupaten Sampang}

Dari Peta Jaringan Sungai Kabupaten Sampang Skala 1:50.000 yang bersumber dari BAPPEDA Kabupaten Sampang seperti tampak pada gambar, terdapat beberapa sungai di Kabupaten Sampang, yang biasanya area di sekitar sungai tersebut sering dilanda banjir. Sungai tersebut adalah Kali Kemuning dan Kali Blega.

\section{Analisa Daerah Potensi Genangan}

Dalam menentukan tingkat potensi daerah genangan, dilakukan overlay atau pertampalan dari berbagai variabel penentu daerah genangan dengan metode skoring, yaitu pemberian bobot dan skor. Dari hasil pertampalan, daerah yang memiliki total skor terbanyak merupakan daerah yang berpotensi genangan. Tabel yang memuat bobot dari setiap variabel penentu daerah genangan, serta skor subvariabel dari masingmasing variabel dapat dilihat pada lampiran.

Pemberian bobot pada tiap variabel bergantung pada tingkat pengaruh variabel tersebut terhadap genangan. Sedangkan pemberian skor pada setiap sub variabel bergantung pada seberapa besar jenis sub variabel tersebut menyebabkan genangan. Semakin tinggi sub variabel berpotensi menyebabkan genangan, maka semakin besar nilai atau skornya. 
Tabel berikut menunjukkan tingkat potensi genangan berdasarkan nilai penjumlahan skor masing-masing parameter genangan.

Tabel 2. Nilai Tingkat Potensi Genangan (Asep Purnama 2008), dengan modifikasi.

\begin{tabular}{clc}
\hline No & $\begin{array}{c}\text { Tingkat Potensi } \\
\text { Genangan }\end{array}$ & $\begin{array}{c}\text { Jumlai Nilai } \\
\text { Semua } \\
\text { Parameter }\end{array}$ \\
\hline 1 & Tinggi & $6,75-9$ \\
2 & Sedang & $4,5-6,75$ \\
3 & Rendah & $2,25-4,5$ \\
4 & Tidak & $<2,25$ \\
\hline
\end{tabular}

Berikut ini adalah Peta Daerah Potensi Genangan berdasarkan pengkelasan sesuai dengan tabel di atas.

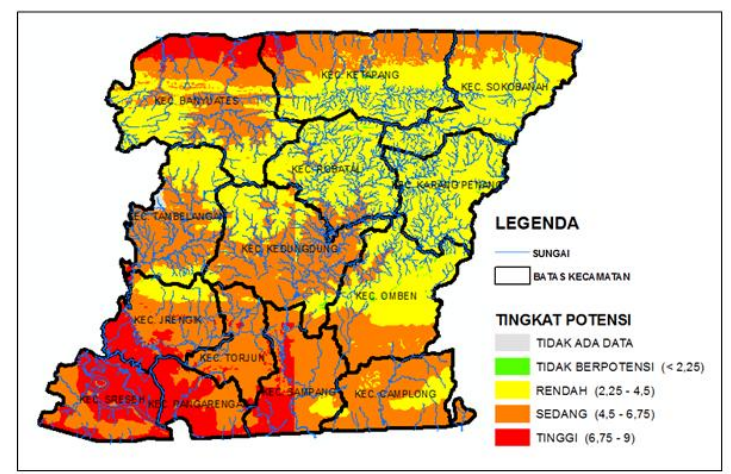

Gambar 12. Peta Daerah Potensi Genangan Kabupaten Sampang

Dari peta tersebut, dapat diketahui bahwa daerah potensi genangan dengan tingkat potensi tinggi berada pada daerah yang relatif datar yaitu dengan kemiringan $0-8 \%$. Hal ini dikarenakan semakin tinggi tingkat kemiringan suatu daerah, maka air akan turun mengalir ke bawah dan tidak menggenang di area tersebut. Daerah potensi genangan tinggi berada pada lahan dengan penggunaan yang paling banyak adalah permukiman. Hal ini dikarenakan pada lahan tersebut merupakan lahan yang padat serta kurang area untuk air dapat bergerak.

Daerah potensi genangan tingkat tinggi sebagian besar berada pada ketinggian 0-12,5 meter. Hal ini dikarenakan prinsip air yang mengalir turun ke bawah, maka semakin rendah suatu daerah, semakin berpotensi daerah tersebut untuk tergenang. Selain itu curah hujan yang tinggi merupakan pemasok utama air yang menyebabkan genangan. Pada tahun 2010, curah hujan di Kabupaten Sampang cukup tinggi, yaitu dengan akumulasi rata-rata 2840,3 mm/tahun. Sehingga Kabupaten Sampang semakin berpotensi untuk tergenang.

Jenis tanah juga merupakan penentu daerah potensi genangan. Dari Peta Daerah Potensi Genangan di atas, daerah berpotensi genangan tinggi didominasi oleh jenis tanah Alluvial Hidromorf. Hal ini dikarenakan jenis tanah Alluvial Hidromorf memiliki tekstur tanah yang sangat halus sehingga menyebabkan sulit untuk infiltrasi air.

Dapat diambil kesimpulan bahwa berbagai faktor yang ada di bumi dapat menyebabkan terjadinya genangan, tidak hanya ketinggian lahan saja. Faktor utama adalah adanya curah hujan yang tinggi sebagai pemasok utama air yang menyebabkan genangan. Namun faktor lain berpengaruh untuk menentukan air yang jatuh tersebut menjadi genangan atau mengalir tanpa hambatan ke laut.

Daerah Potensi Genangan tinggi berada pada Kecamatan Sampang, Sreseh, Banyuates, Jrengik, Pangarengan, Torjun, dan Ketapang. Daerahdaerah potensi genangan tinggi tersebut berada dekat dengan jaringan sungai seperti Kali Kemuning, Kali Blega, Kali Barangkok, dan lain sebagainya.

Dari data kejadian banjir, area yang tergenang adalah area di Kecamatan Sampang. Hal ini cocok dengan Peta Daerah Potensi Genangan yang dihasilkan, dimana tampak pada gambar, area Kecamatan Sampang sebelah barat didominasi oleh area dengan tingkat potensi genangan yang tinggi. Kecamatan Sampang memang area yang sangat berpotensi tergenang karena memiliki wilayah yang relatif datar dan rendah, curah hujan yang tinggi, jenis tanah yang kurang mendukung terjadinya infiltrasi, serta merupakan area perkotaan yang padat penduduk sehingga kurang area resapan air. Selain itu, Kecamatan Sampang dilewati oleh Kali Kemuning yang memiliki alur yang berkelok-kelok dan dangkal akibat sedimentasi yang tinggi serta lebar yang tidak cukup untuk menampung kiriman air sungai dari 
daerah utara pada saat hujan lebat. Pada Kecamatan lain, belum terdapat laporan terjadinya banjir yang mengakibatkan genangan. Namun bukan berarti daerah tersebut tidak berpotensi untuk tergenang. Contohnya saja area di sekitar Kali Blega, area tersebut merupakan area yang relatif rendah dan datar serta dekat dengan sungai. Tetapi, karena area tersebut bukan merupakan area perkotaan dan bukan area padat penduduk, apabila area tersebut tergenang tidak akan terlalu merugikan. Hal ini yang menyebabkan belum ada laporan mengenai kejadian banjir di area tersebut.

Pada Kecamatan Banyuates, dari hasil analisa didapatkan area yang berpotensi genangan tinggi, namun pada data lapangan belum ada hal yang menyebutkan seperti itu. Hasil analisa, menunjukkan area yang berpotensi genangan tinggi pada Kecamatan Banyuates memiliki kriteria sebagai area yang berpotensi tergenang. Selain karena area tersebut datar dan rendah, juga berada di daerah aliran sungai dan memiliki jenis tanah yang permeabilitasnya lambat. Oleh karena itu kedepan perlu adanya penelitian yang membahas daerah potensi genangan di wilayah utara Sampang terutama di Kecamatan Banyuates agar dapat mengetahui kebenaran dari hasil analisa ini.

Peta Daerah Potensi Genangan tersebut diambil sampel dari daerah dengan tingkat potensi genangan tinggi pada empat Desa atau Kelurahan yaitu Paseyan, Dalpenang, Panggung, dan Gunungmaddah untuk divalidasi dengan data kejadian banjir tahun 2010 menggunakan analisa korelasi.

Dari hasil analisa korelasi, diperoleh korelasi 0,796 antara sampel potensi genangan tingkat tinggi dari hasil analisa dengan luas genangan dari data kejadian banjir tahun 2010. Korelasi tersebut diuji dan dihasilkan kesimpulan bahwa ada hubungan yang signifikan antara sampel potensi genangan tingkat tinggi dari hasil analisa dengan luas genangan dari data kejadian banjir tahun 2010 pada tingkat signifikan $30 \%$ atau tingkat kepercayaan $70 \%$. Hal ini berarti terdapat hubungan yang cukup erat antara sampel potensi genangan tingkat tinggi dari hasil analisa dengan luas genangan dari data kejadian banjir tahun 2010.

Berikut ini digambarkan scatter plot dari kedua data yang dibandingkan tersebut. Dimana $Y$ adalah sampel luas daerah potensi genangan tingkat tinggi dari hasil analisa dan $\mathrm{X}$ adalah luas genangan dari data kejadian banjir tahun 2010. Dari gambar tersebut dapat diketahui bentuk persamaan regresi linier dari kedua hal tersebut yang tampak saling mempengaruhi, dimana semakin besar nilai $X$ semakin besar pula nilai $Y$.

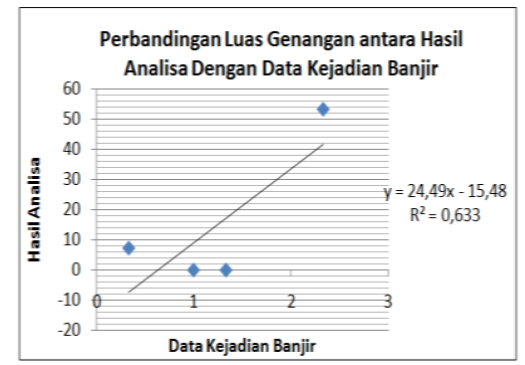

Gambar 13. Scatter Plot Luas Hasil Analisa Daerah Potensi Genangan Sangat Tinggi dan Luas Genangan dari Data Kejadian Banjir

\section{Analisa Hubungan antara Curah Hujan dengan Genangan}

Analisa hubungan dilakukan antara intensitas curah hujan dengan tingkat potensi genangan. Analisa dilakukan dengan menggunakan tabel kotingensi yang terbentuk sebagai berikut.

Tabel 3. Tabel Kontingensi Intensitas Curah Hujan dengan Tingkat Potensi Genangan.

\begin{tabular}{cccccc}
\hline $\begin{array}{c}\text { Curah Hujan } \\
\text { (mm/tahun) }\end{array}$ & $\begin{array}{c}\text { Tidak } \\
\text { Berpotensi }\end{array}$ & Rendah & Sedang & Tinggi & Total \\
\hline 2780.2 & 210 & 7953 & 3405 & 0 & 11568 \\
2790.6 & 300 & 23030 & 4713 & 30 & 28073 \\
2889.8 & 8 & 4048 & 5116 & 1046 & 10218 \\
2900.6 & 0 & 4320 & 3456 & 603 & 8379 \\
Total & 518 & 39351 & 16690 & 1679 & 58238 \\
\hline
\end{tabular}

Pengolahan data dengan metode tabel kontingensi dalam tugas akhir ini menggunakan perangkat lunak SPSS Statistics 17.0. Hasil pengolahan tersebut ditunjukkan dengan output hasil Uji Chi-Square. 


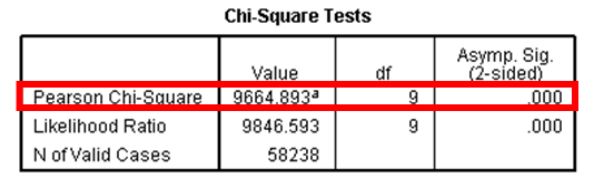

Gambar 14. Tabel Chi-Square Test

Nilai Chi-Square hitung dapat dilihat pada Value Pearson Chi-Square. Karena nilai tersebut lebih besar dari nilai Chi-Square tabel $(16,9)$ maka Ho ditolak. Sedangkan nilai probablilitas dapat dilihat dari kolom Asymp Sig (2 Sided). Karena Asymp. Sig-nya adalah 0,000 yang berarti lebih kecil dari 0,05, maka Ho ditolak. Sehingga dapat disimpulkan bahwa ada hubungan antara baris dan kolom yang berarti ada hubungan antara intensitas curah hujan dengan tingkat potensi genangan.

\section{KESIMPULAN DAN SARAN}

\section{Kesimpulan}

Berdasarkan hasil penelitian tentang pemetaan hutan menggunakan algoritma NDVI dan EVI, maka didapatkan beberapa kesimpulan akhir dari penelitian ini, yaitu:

a. Estimasi curah hujan di Kabupaten Sampang dapat diketahui dengan menggunakan data TRMM. Hal ini dibuktikan dengan adanya korelasi yang tinggi yaitu 0,649 (tahun 2010), 0,747 (tahun 2009), dan 0,882 (tahun 2008) antara data curah hujan TRMM dengan data curah hujan BMKG.

b. Daerah potensi genangan dengan tingkat potensi tinggi berada pada daerah yang relatif datar yaitu dengan kemiringan 0-8\%, ketinggian 0-12,5 meter, penggunaan lahan yang paling banyak adalah permukiman, jenis tanah Alluvial Hidromorf, dan curah hujan $2889,8 \mathrm{~mm} /$ tahun.

c. Dari hasil analisa, terdapat daerah potensi genangan yang berada di utara Kabupaten Sampang, hal ini dikarenakan pada area tersebut daerahnya relatif rendah dan datar serta memiliki intensitas curah hujan yang tinggi. Namun belum ada data yang membuktikan hasil analisa tersebut.

d. Analisa hubungan antara intensitas curah hujan dari data TRMM dengan tingkat potensi genangan menggunakan tabel kontingensi, menunjukkan bahwa terdapat hubungan antara intensitas curah hujan dengan tingkat potensi genangan. Hal ini dibuktikan dengan

\section{Saran}

a. Penggunaan data TRMM sebagai data curah hujan untuk analisa potensi genangan sangat dianjurkan, karena memiliki hubungan yang erat dengan data curah hujan di lapangan serta berkaitan dengan tingkat potensi genangan.

b. Perlu adanya penelitian mengenai kebenaran dari hasil analisa potensi genangan yang terdapat pada area sebelah utara Kabupaten Sampang, tepatnya di Kecamatan Banyuates.

\section{DAFTAR PUSTAKA}

Fitrianto, Dhany. 2009. Pengelolaan Lahan Daerah Aliran Sungai (DAS) Kemoning untuk Meminimalisasi Terjadinya Banjir Pada Daerah Hilir DAS Kemoning di Kabupaten Sampang-Madura.

Frenberg, S.E. 1985 The Analysis of cross classified Categorical Data.

Guilford, J.P. 1956. Fundamental Statistics in Psychology and Education. (p. 145). New York: McGraw Hill.

Gunawan dkk. 2008. Pemanfaatan Data Curah Hujan Satelit TRMM untuk Database Zona Prakiraan Musim. Program Intensif Riset Terapan. BMKG.

Kompas (Jakarta). 2012. 13 November.

Lukman, Taufik, dan Wiweka. 2011. Aplikasi SIG Untuk Penyusunan Data Pokok Penunjang Evaluasi Daerah Rawan Genangan Di Surabaya. Tugas Akhir. Surabaya : Program Studi Teknik Geomatika.

Prajitno, Djoko. 1981. Analisa Regresi - Korelasi. Yogyakarta : Liberty.

Primayuda A, 2006. Pemetaan Daerah Rawan dan Resiko Banjir Menggunakan Sistem Informasi Geografis: studi kasus Kabupaten Trenggalek, Jawa Timur. Tugas Akhir. Institut Pertanian Bogor.

Purnama A, 2008. Pemetaan Kawasan Rawan Banjir Di Daerah Aliran Sungai Cisadane Menggunakan Sistem Informasi Geografis. Tugas Akhir. Institut Pertanian Bogor.

TRMM Office. 2013. TRMM Brochure. Goddard Space Flight Center. Greenbelt. Maryland.

Utomo W. Y. 2004. Pemetaan Kawasan Berpotensi Banjir di DAS Kaligarang Semarang dengan Menggunakan Sistem Informasi Geografis. 
Tugas Akhir. Bogor: Fakultas Pertanian, Institut Pertanian Bogor.

Zubaidah, Ani, Roswintiarti, O, dan Suwarsono. 2011.

Pemanfaatan Data Curah Hujan Global
Berbasis Penginderaan Jauh untuk Pemantauan Daerah Potensi Banjir (Studi Kasus Provinsi Sulawesi Selatan). Inderaja Volume II No.2 Juli 2011. 


\section{LAMPIRAN}

Tabel Skoring Variabel Penentu Daerah Potensi Genangan

\begin{tabular}{|c|c|c|c|c|}
\hline Variabel & Bobot\% & Sub Variabel & Skor & Total \\
\hline \multirow{6}{*}{ Curah Hujan } & \multirow{4}{*}{20} & 2780,25 & 1 & 0.2 \\
\hline & & 2790,578 & 3 & 0.6 \\
\hline & & 2889,781 & 5 & 1 \\
\hline & & 2900,614 & 7 & 1.4 \\
\hline & \multirow{6}{*}{30} & $0-12,5$ & 9 & 2.7 \\
\hline & & $12,5-25$ & 7 & 2.1 \\
\hline \multirow{8}{*}{ Ketinggian Wilayah } & & $25-50$ & 5 & 1.5 \\
\hline & & $50-75$ & 3 & 0.9 \\
\hline & & $75-100$ & 1 & 0.3 \\
\hline & & $100-250$ & 0 & 0 \\
\hline & \multirow{10}{*}{10} & Aluvial Hidromorf & 9 & 0.9 \\
\hline & & Aluvial Kelabu Kekuningan & 9 & 0.9 \\
\hline & & Asosiasi Hidromorf Kelabu dan Planosol Coklat Keke & 3 & 0.3 \\
\hline & & Asosiasi Litosol dan Mediteran Coklat Kemerahan & 7 & 0.7 \\
\hline \multirow{6}{*}{ Jenis Tanah } & & Grumusol Kelabu & 9 & 0.9 \\
\hline & & Kompleks Brown Forest Soil, Litosol Mediteran & 5 & 0.5 \\
\hline & & Kompleks Grumusol Kelabu dan Litosol & 7 & 0.7 \\
\hline & & Kompleks Mediteran Merah dan Litosol & 7 & 0.7 \\
\hline & & Kompleks Mediteran, Grumusol, Regosol, dan Litosol & 5 & 0.5 \\
\hline & & Litosol & 7 & 0.7 \\
\hline \multirow[t]{16}{*}{ Tutupan Lahan } & \multirow[t]{16}{*}{10} & Empang & 9 & 0.9 \\
\hline & & Garam & 9 & 0.9 \\
\hline & & Hutan Lindung & 1 & 0.1 \\
\hline & & Hutan Produksi & 1 & 0.1 \\
\hline & & Hutan Produksi Terbatas & 1 & 0.1 \\
\hline & & Kawasan Resapan Air & 1 & 0.1 \\
\hline & & Kebun & 3 & 0.3 \\
\hline & & Pasir Laut & 9 & 0.9 \\
\hline & & Perikanan Tambak & 9 & 0.9 \\
\hline & & Permukiman & 6 & 0.6 \\
\hline & & Pertanian Tanaman Pangan & 8 & 0.8 \\
\hline & & Rumput & 5 & 0.5 \\
\hline & & Tanah Ladang & 8 & 0.8 \\
\hline & & Terumbu Karang & 9 & 0.9 \\
\hline & & $0-8 \%$ & 9 & 1.8 \\
\hline & & $8-15 \%$ & 7 & 1.4 \\
\hline \multirow[t]{3}{*}{ Kelerengan } & \multirow[t]{3}{*}{20} & $15-25 \%$ & 5 & 1 \\
\hline & & $25-40 \%$ & 3 & 0.6 \\
\hline & & $40-70 \%$ & 1 & 0.2 \\
\hline
\end{tabular}

